leave, they were welcome in the West as refugees. Now that Eastern Europeans are free to leave, they cannot come, because the West will not admit them.

Europe, which was divided before by the Cold War, remains divided by migration controls. The Helsinki process, the process of confidence building measures through human contact, generated by the Final Act of the Conference on Security and Cooperation in Europe signed in Helsinki in 1975, remains frustrated because freedom of movement within the Helsinki space is restricted. Migration controls cut the Helsinki space in two. The concept of Europe-the ideal of the Helsinki process - can be made to work only if migration controls end, and if racism in migration policies ends.

To return to the original question: how do we combat racism against refugees and migrants? The battle against racism directed towards refugees and migrants cannot be fought only at the level of grand anti-racist principles and schemes. It must be fought also at the level of technical detail of refugee and migration policies. Demonstrations and prosecutions against racism are not enough. Even human rights, affirmative action, and reasonable accommodation programs are not enough for a generous interpretation of the refugee definition.

In addition, we have to fight for fair procedures, accurate assessment of source country condition information, and reasonable credibility assessment. We have to work to ensure our governments each admit their fair share of refugees in need of resettlement abroad. We need to stand for a safe haven for all those fleeing forced $\mathrm{mi}$ gration. We must be on the side of ready access to nationality for migrant residents. We must promote the principle of family unity for migrants and refugees.

We must be prepared to marshall the arguments which show that migration helps the domestic economy. Finally, we must endorse freedom of movement for all. Only then will the battle against racism inflicted upon refugees and migrants be fully joined.

\title{
Live Again in Community: Hispanic Refugees and the Church
}

\author{
John F. Duggan, S.J.
}

Torture and other forms of physical assault are systematic attempts to undermine a personal sense of safety by violating our most symbol-laden possession, our body. Often victims of torture are stripped in the torture process, a gesture that emphasizes the vulnerability we all experience just below the surface of our lives. (Schreiter, 33)

It was my personal friendship with Salvadorans that led me in 1988 to become involved in starting a Spanish language mass at St. Thomas More Church, just east of the corner of Markham and Ellesmere in Toronto. Although the mass was a new beginning at this particular parish, the group that came to the liturgy were already a community with their own history in Canada. In a general way, I knew they were people who had escaped a situation of guerrilla war and brutal repression that continued over the last decades in El Salvador. While studying Spanish language and theology in Mexico City in late 1982, I had been involved in translating a torture testimony. I was aware of the specific inhumane obscenities practised by the torturers. However, until I asked questions about the founding of the St. Thomas More community I did not know how tightly tied this community was to the trauma of torture. To know that history is to recognize the cross at the centre of their personal experience and religious vision. It is to recognize also that their experience of oppression and marginalization did not end when they came to a new land.

\section{Remembering the Story of the Community}

This account draws on conversations with central members of the community and a number of counsellors working with them. It depends also on my own acquaintance with the community. I have tried to correct and

Dr. John F. Duggan, S.J., teaches pastoral theology at Regis College, Toronto and is the President of Catholic Immigration Bureau of Archdiocese of Toronto. revise the account as I received feedback on earlier drafts.

For some of these newcomers to Canada the past intrudes on the present and there is no escape from the concerns of their distant homeland. A worker for the Catholic Immigration Bureau tells her story. She discovered that both a torture victim and his torturer were approaching her for counselling. By some strange coincidence these two, whose lives had been so horribly joined in their homeland of $\mathrm{El}$ Salvador, found themselves in one of the tall, multi-dwelling apartment buildings of Scarborough living on the same floor with their apartment doors facing one another across the hallway. The torturer had been in the lower echelons of the army and had been assigned the dirty work of torture. He had fled the army and been captured and in turn brutally tortured himself. The person he had tortured, knowing that the torturer was living just across the hallway was afraid to go out the front door of the apartment. The counsellor carefully scheduled separate appointments so that the two would not encounter one another. To complete the scenario a third Salvadoran lived next door to the tortured person. This person was also a refugee, neither torturer nor tortured, but displaced from their homeland by the general conditions of war.

This is a single episode that sets a local context to the life of the worshipping community that grew as a response to the needs of one group of newcomers to Canada in the early 1980 s. The Spanish language Mass that has been celebrated in Scarborough for the last decade emerged from a therapy group for Salvadoran refugees 
who had been tortured. The group was called OASIS. Members of that early torture therapy group still participate at the heart of the life of the St. Thomas More Hispanic community. However, to speak of the St. Thomas More Hispanic community is to jump over the beginning years of the community.

\section{Beginnings in Scarborough}

In 1982 there began an influx of refugees from El Salvador into the Scarborough region of Metropolitan Toronto. Miranda Pinto, who had been involved in pastoral ministry among the poor in Peru, was hired by the Catholic Immigration Bureau (CIB) to set up an office in St. Boniface Church on Markham Road. As she moved into her relationship with the Hispanics in the area, Miranda found herself conscious of something not being said, particularly by the men who would pass time at the CIB office. Finally, one of the men in talking to her broke down and spoke of being gang-raped while in custody. The dilemma was that this tortured man and others like him felt they could not talk to either men or women about their experience. They were fearful of men and embarrassed to talk to a woman. The affirmation and positive response of that first encounter between this one man and Miranda led to many others coming forward with their stories. Very quickly, Miranda found herself overwhelmed by the demands on her skills, time and energy. She worked by herself for the first six months until a second staff person, a male counsellor, was hired.

Further help came in the person of two church volunteers. Miranda wrote up the project proposal that brought into the work two returned missionaries, Robert Smith of the Oblates of Mary Immaculate and Betty Dilio a religious Sister of the Congregation of the Holy Cross. These two, who had worked together in Peru, began ministering to Hispanics in the Scarborough area in 1983. Father Bob and Sister Betty were delegated by their communities and joined with Miranda Pinto out of the CIB's office in the basement of St. Boniface Church on Markham Road north of Eglinton. At a later point (1984), Sister Betty was taken on in a staff position at the CIB.

During this period, Central Americans, primarily from El Salvador, were beginning to arrive in Canada and a good number were finding apartments in the Scarborough area. Many of these early arrivals had been, for the most part, politically active in El Salvador. They had experienced the trauma of harassment and torture by the military and death squads of that country. With Miranda, Father Bob and Sister Betty drew on their experience of forming community in Peru in order to begin to shape a community. They held Bible studies and entered into a process of leadership formation. Many of the Salvadorans, alienated from the Church in their own country, who at first had looked on this nascent community purely as a base for organizing political and financial support for the struggle in El Salvador, began to experience what Sister Betty has termed a 'conversion'. They began to find real value as well in community life, prayer and worship as they experienced healing within community and were strengthened for the challenges of life. In the struggle against the forces of degradation from their past they were able to recover dignity and meaning by linking their "narratives to other, larger narratives" (Schreiter 1992, 34). The celebration of community worship became a zone of safety in which to join personal stories with the larger Gospel story. The community benefited from the openness of Father Tom Day of St. Boniface Parish. Father Day gave the Hispanics a sense that they were welcome in the church, he presided at weekly liturgy in his own struggling Spanish and he encouraged leadership formation. He was aided in his ministry by an experienced Salvadoran church worker.

\section{The Arrival of the Catechists}

The tenor of the religious life of the small community was affected by the next influx of refugees from El Salvador in 1984. At this timé in El Salvador the military and the death squads had begun to actively attack, torture and murder church workers. Many catechists were killed and some managed to escape the country. The new group of arrivals in Scarborough brought with them pastoral knowledge and skills that they had learned in the small church communities of $E$ l Salvador. They were committed to the church and competent to evangelize and to prepare their fellow community members for sacraments and participation in ministries in the church community.

Helpful background to understand this group of catechists is the book Don Lito of El Salvador (Vigil 1990). This is the record of a series of conversations with a Salvadoran campesino, a committed Catholic and an activist. The conversations were taped in 1981 by Maria Lopez Vigil and transcribed and supplemented by factual information and photos for the book. Don Lito recalls his own transition from being the trusted assistant of the priest in a situation in which the church and priest blessed the status quo of exploitative government and poverty. Inspired by a younger priest sent to replace the former pastor, Don Lito grew in awareness of the relation between the Word of God and the more fully human community. From being concerned with fiestas and processions his church community re-centred on forgiveness and helping one another. The Catholic church under the leadership of Monseñor Romero and some dedicated priests and many devoted catechists became identified with the poor. The conversations record the involvement of ORDEN and other organizations in the life of the campesino, the successful manipulation of some and the growing awareness and radicalization of others. Don Lito laments the murder of many of his friends and recalls the hardships of times spent hiding in the hills. What is remarkable is the continuing strength of his faith in Christ, his lack of fear of death and his desire to treat those who opposed him not as enemies but as friends. 


\section{The Chariamatics}

At this time (1984-1985), another kind of group was arriving from El Salvador, those who had been influenced by the charismatic movement. Though they were relatively apolitical, the climate of paranoia in El Salvador had made them suspect. From the perspective of the security mentality any people who gathered in groups for whatever purpose were considered dangerous. These Roman Catholics affiliated to the charismatic movement began to experience threats and to feel insecure and therefore sought means to flee the country. Their addition to the community in Scarborough at St. Boniface's added resources of prayer and religious practice but also brought tensions. The charismatics tended to work independently of the normal leadership and in their enthusiasm they sometimes gave the impression to others that they considered themselves superior in spiritual experience. For the most part, the longer they were involved with the community, the more they grew to be enthusiastic and supportive members.

\section{The Chileans}

After a few years Father Smith left for another assignment and Sister Betty carried on the pastoral ministry. Sister Betty and Miranda Pinto were, at the same time, involved in the daily routine of settlement work for the CIB. Many of the clients of this settlement agency were Hispanics and also participated in the life of the Hispanic Roman Catholic community that met at the church. During these years, the worship community also benefited from the support of Scarborough Foreign Mission priests on leave from pastoral assignments in Latin America. The community developed an effective and dynamic youth group and an enthusiastic and talented music group. Numbers during this time at the liturgies were in the range of 80 to 100 . There was a liturgy planning committee that encouraged families to take responsibility for particular liturgies. The masses were lively, often includ- ing dramaticre-enactments of the Gospel. As the mass became more of a public event advertised in the community it began to attract Chileans from the apartments nearby. The Chileans included some who had conservative notions of church life.

The Chileans who came to Canada with the overthrow of Allende in 1973 were of socialist and communist party background. They were campesinos and unionists fleeing a policy of murder and torture systematically carried out by the Chilean military under the direction of General Pinochet. The Chileans who came later in the 1980 s tended to be of the middle class, religiously more traditional, Christian Democrats frustrated by the lack of opportunity for political expression and seeking economic opportunities. They preferred not to be intensely involved in the community life. They were not happy with the demands put on them by the community and some vehemently protested the requirements for baptismal preparation. The pastoral leadership group thus found themselves at times in conflict with members of the Chilean community.

\section{The Nicaraguans}

The community benefited in 1985-86 from the assistance of a member of the Holy Cross congregation, Santiago Mendes-Vides, a student of theology in the Master of Divinity programme at St. Michael's College. Santiago, a citizen of Guatemala, was especially interested in the formation of leaders and dedicated himself enthusiastically to various programmes with the community. Nicaraguans also began to arrive in the area. Many of this group were traditional in their view of church life. As with the Chilean group many of them would attend but not actively participate in the life of the community. In Nicaragua, the influence of the popular (progressive) church within the institutional church had declined significantly since the coming to power of the Sandinistas in 1979. It has encountered the opposition of both the Nicaraguan hierarchy and the Vatican. As well, it has not been able to discover a clear role for itself within the revolutionary process after the overthrow of Somoza. The progressive church works with a communitarian model of church, with authority residing in the Basic Ecclesial Communities, with the priest functioning as a partner in the church communities. As well, the progressive church relates more directly to the oppressed classes. This "preferential option for the poor" clearly has political implications (Williams 1992, 129-130). The Nicaraguans who arrived in Canada were predominantly those who were alienated from the Sandinista government and the popular church that supported it. The Salvadorans in the community were those who have had positive links to the popular church in El Salvador and were alienated from the military and ARENA dominated government. Santiago's skills as a facilitator and reconciler came more and more in demand.

\section{The Dispersal}

In 1987 , the community experienced a major crisis. The pastor of the parish where the community gathered, Father Tom Day, was transferred from St. Boniface to another church in the centre of Toronto, St. Paul's. The incoming pastor, a priest from Malta, simply did not want the Spanish community at this church. His stated rationale for this position was that there were other ethnic groups in the parish, like the Filipinos and Italians, who had not asked for their own language mass. Sister Betty and the other $\mathrm{CIB}$ workers could find no way forward at that point. The members of the community dispersed, some attended liturgy at St. Peter's in the centre-city, while others simply stopped participating in church life. Sister Betty and Miranda Pinto continued to work in their settlement and advocacy roles out of the office of the Catholic Immigration Bureau in the basement of the church. It was a point of interest to note that the pastor allowed the Spanish-speaking charismatic prayer group to continue to meet at St. Boniface. In 1989 the Scarborough office of the CIB transferred from the basement of St. Boniface to another

Refuge, Vol. 13, No. 8 (January 1994) 
location on Heron Avenue in the buildings of the St. Joseph community across from Providence Villa.

\section{The Community Comes to Life Again}

It was on the occasion of a visit to my friends, a Salvadoran family I was close to, that I heard of the dispersal of the community that had been celebrating at St. Boniface Church. Don Victor Alegre, a Salvadoran and a central figure in the life of the community, laid before me the problems. At that time I was still an Associate Pastor at Our Lady of Lourdes but had recently finished my work on a Doctor of Ministry (Duggan 1987) and was ready to take on further responsibilities. I felt close to the Hispanic community and so I volunteered to do what I could if a church was arranged for the mass. Don Victor promised to talk with the members of the community and particularly to Santiago Mendes-Vides about the possibility of reactivating the mass. Don Victor also undertook to talk with the acting pastor of St. Thomas More church where he was a parishioner. A later phone call confirmed that we were ready to begin the liturgy, the people informed and the parish ready to give us a time on Sunday afternoon.

We celebrated our first liturgy at St. Thomas More on September 18, 1988. In those early years (1988-1991) at St. Thomas More the community benefited from the capable involvement of Santiago Mendes-Vides and Tony Cosentino. The community attempted to model its structure on that of the small faith communities that the people were familiar with from their own countries. This has meant that much of the ministry is carried out by members of the community. There has been a high level of participation in community life and decision making. Both Santiago and Tony have moved on to other involvements. Santiago is ordained as a priest for the Holy Cross Order and this time is working in Peru. Tony, after a stint with the CIB in the Scarborough area as a full-time worker dealing with Hispanics, pursues further studies. Most recently, he has been working one day a week for the Toronto office of the CIB stimulating refugee sponsorships in the parishes. Otherwise, he is to be found with guitar and flute busking in the Toronto subways.

\section{Good Friday People}

As interworked systems of construable signs ... culture is not a power, something to which social events, behaviours, institutions or processes can be causally attributed; it is a context, something within which they can be intelligibly - that is, thicklydescribed. (Geertz, 14)

St. Thomas More church is a low modern style structure built some $\mathbf{3 0}$ years ago, to the back of which is attached the parish rectory with offices and quarters for the priests. Coming along Ellesmere, I kept my bicycle close to the curb aware that I was an alien and unexpected event on these thoroughfares built with only automobiles in mind. It was just coming up to 11:00 a.m. when I walked into the church. There were very few people there, although from what Porfirio had told me the way of the cross was scheduled for 11:00 a.m. Don Victor Alegre caught my eye as he was wearing a suit, an unusual practice for him. I greeted the people and moved quickly across the sanctuary and back into the sacristy. I sat down with the sacramentary to study the service. Soon Father John, an Associate Pastor in the parish who had been helping with the ministry to the Hispanic community, came in. He told me that he would be with me in the service to help out. He also told me that the church was not able to accommodate the Sunday afternoon Easter liturgy for the Hispanic community. This was unacceptable and I asked him to phone a nearby parish to see whether or not we could say the mass there. Father John soon returned looking relieved to say that, yes, Saint Rose of Lima parish on Lawrence Avenue could accommodate us at our regular 4:00 p.m. time Sunday afternoon.

Meanwhile, the way of the cross led by Don Victor had begun in the church about 20 minutes after the scheduled starting time. When I looked out the church was filling up. As the hour approached noon, Father John and myself vested in the red robes of the Good Friday liturgy and were led by two altar boys with their candles into the church. We walked in silence down a side aisle and then up the centre aisle to stretch out prostrate in front of the altar. After a few minutes we rose and went around the altar to begin the service with an opening prayer. The service was a long one with of a reading of the passion in the Gospel of John-the narrator and Pilate at a microphone on the left of the altar, myself as Jesus in the centre and Sister Eszaura and Marissa at the lectern on the right as Peter, the crowd and the various servants. I gave a short homily and Father John and I sang the special prayers of petition. Then came the carrying of the large, wooden cross from the entrance of the church up the main aisle singing three times "Mirad el arbol de la cruz ...". (Behold the wood of the cross). After Father John and I venerated the cross, the people came forward. With devotion and one by one-the congregation by now had grown to some 300 people-they knelt and then touched or kissed the cross. This was done in a solemn and orderly fashion while the choir sang a lament. Father John at one point whispered across to me-"Is there any way we can speed this up?" I couldn't think of a way to do this gracefully and so answered "no." The people were showing their devotion and I could not see denying them that opportunity.

The veneration of the cross was followed by preparation of the altar for the communion service. At this point, two ushers went down the rows to collect whatever offering the people might make. Father John had gone into the sacristy to process in with the two saboria. After giving the host to the two altar boys, both of us went around the front of the altar to distribute communion. The communions went quickly and the choir sang once again. Then there was an announcement by one the pastoral council that the Easter mass had been changed to St. Rose of 
Lima. After that, I said the final prayer and blessing and we left the altar in silence directly into the sacristy.

The event of this Good Friday service has been too briefly described. The people of this community are well-acquainted with suffering. They have experienced persecution and torture. They have fled the land they loved. Coming from lands of sunshine and warmth they have struggled to establish themselves in a cold and sometimes humanly inhospitable country. The long service of adoration of the cross is a symbol of their own deep relationship to the challenge of suffering. They linger at the cross of Jesus. The tension for the "Canadian" presiders is that punctuality and efficiency are high values within our own culture. We feel under our own self-generated pressure to move the service along more expeditiously.

The decision not to make the church available for the Easter Sunday mass of the Hispanic community invites reflection. From the perspective of the community it is a denial of the opportunity to celebrate Easter fully in one's own language, with one's own people. Considered symbolically, it stirs memories of other attempts to deny these people their experience of resurrection. The activities of the death squads, the subversive strategies of the power brokers at the centre of the American empire, and the hostile reading of the popular church by local bishops and Vatican bureaucrats have conspired to deny life. From another perspective it is simply a hasty decision in a mainline suburban church with too much going on and too few priests. The community adapts and there is good turnout at St. Rose of Lima on Easter Sunday. The generosity of that parish is a healing balm for the feelings of rejection.

One reason for the tensions that developed between the main church and the Hispanic community was that the main parish office could not handle the many Spanish speaking people coming with their requests. Father John, the priest on staff who had been helping with the Hispanics, was overburdened by his various responsibilities.
The community was once again threatened with dispersal. My attendance at the meetings of the Spanish-speaking priests have acquainted me with Bishop Nicola De Angelis, a newly consecrated bishop responsible for the ethnic communities. On learning of the tensions between the parish and the Hispanic community the bishop intervened to support the community.

At the end of August of 1993, the Hispanic communities gathered for a liturgy with Bishop De Angelis at Midland on the grounds of Martyr's Shrine. For the first attempt to gather a Hispanic pilgrimage group, this was a successful event with representatives present from the six Hispanic worship communities in the Metropolitan area. Well over 2,000 people were in attendance. The high point of the liturgy was a dramatization of the Gospel spearheaded by the youth of St. Thomas More Hispanic community. The bishop was obviously moved and thanked the youth for their presentation: "Mother Church loves you," he said. At the altar and again at the end of the day the bishop told me how impressed he was by the presentation the youths made.

\section{Happy Endings so Far}

I arrived for the liturgy one Sunday afternoon early in September 1993 to discover that bishop responsible for the eastern zones of the Archdiocese, Bishop John Knight, was making a visit to the whole parish. He had decided to preside at the Spanish mass and to preach. He told me that he had made it clear to the church that the Spanish mass was to be considered a ministry of the whole parish and that it was to be supported. Bishops De Angelis and Knight took a strong stance in support of the St. Thomas More Hispanic community. Very soon after this, the pastor hired Porfirio Garcia to be in the parish one day a week and to ensure that there was proper communication between the parish and the Spanish-speaking people seeking pastoral services.

Since the departure of Santiago the coordinator of the community has been Porfirio Garcia, originally from
El Salvador. Porfirio combines studies in theology at Regis College of the Toronto School of Theology with parttime work. Porfirio's wife Marissa also demonstrates the new level of integration being achieved by Hispanics in the Canadian church. Marissa has completed her courses for the Master of Divinity and will soon graduate from St. Michael's College with her degree. At present, the members of the St. Thomas More Hispanic community are feeling more rooted and their community has been more actively embraced by the local church and its bishops.

\section{The St. Thomas More Hispanic Community Today}

Today, in January of 1994, the St. Thomas More Hispanic community is larger and more diverse. The membership is comprised of some 400 or more people primarily from El Salvador and Nicaragua but also from other Latin American countries such as Panama, Colombia, Chile, Peru and Guatemala. There are even a few active members who are Canadian born but attend the 4 p.m. Sunday eucharist with Hispanic friends and are eagerly learning to speak Spanish. The community is directed by the pastoral council of some 20 people who try to meet every three weeks.

There is an active choir of 25 people supported by guitars, a social committee that arranges recreational outings during the summer and facilitates coffee and doughnuts after the Sunday service, and senior members of the community who do baptismal preparation, give pre-matrimonial talks and prepare children for their first communion. A religious sister, Sister Eszaura, has been helping with the youth group of the community. Each week one member of the community, a Nicaraguan, prints out a bulletin for the community. There are occasional events like retreats for the whole community, opportunities for couples to do marriage encounters, and appeals for financial and personal support for particular people in need. On various occasions talks relating to immigration 
status and settlement needs have been held after the liturgy in the parish hall. More and more English is heard spokeriamong the young children of the community.

We can expect that the St. Thomas More Hispanic community will meet new challenges as second and third generation children mature. My confidence is that the community will always draw on the courage and faith of its first founding group-those tortured people who have met the challenge to live again in community.

\section{References}

Duggan, John. 1987. Religious Experience and the Multicultural Church Community. unpublished doctoral thesis. Toronto: Regis College, Toronto School of Theology.

Geertz, Clifford. 1973. The Interpretation of Cultures. New York: Basic Books

Schreiter, Robert J. 1992. Reconciliation: Mission and Ministry in a Changing Social Order, Vol.3. Maryknoll, New York: Orbis Books,

Vigil, Maria Lopez. 1990. Don Lito of El Salvador. Tanslated by Orbis Books. Maryknoll, New York: Orbis Books.

Williams, Philip. 1992. "The Limits of Religious Influence: The Progressive Church in Nicaragua." In Conflict and Competition: The Latin American Church in a Changing Environment, edited by Edward 1. Cleary and Hannah Stewart-Gambino. Boulder, $\mathrm{CO}$ and London: Lynne Rienner Publishers.

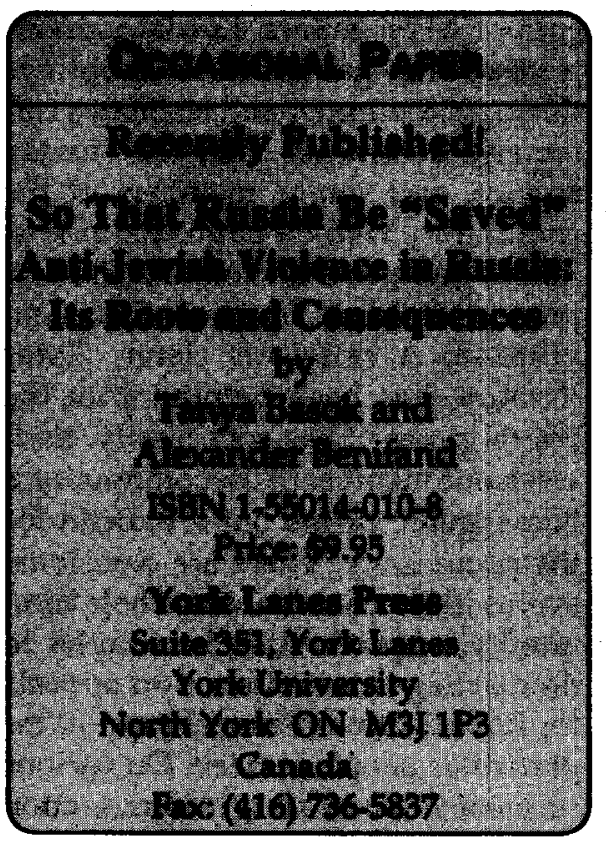

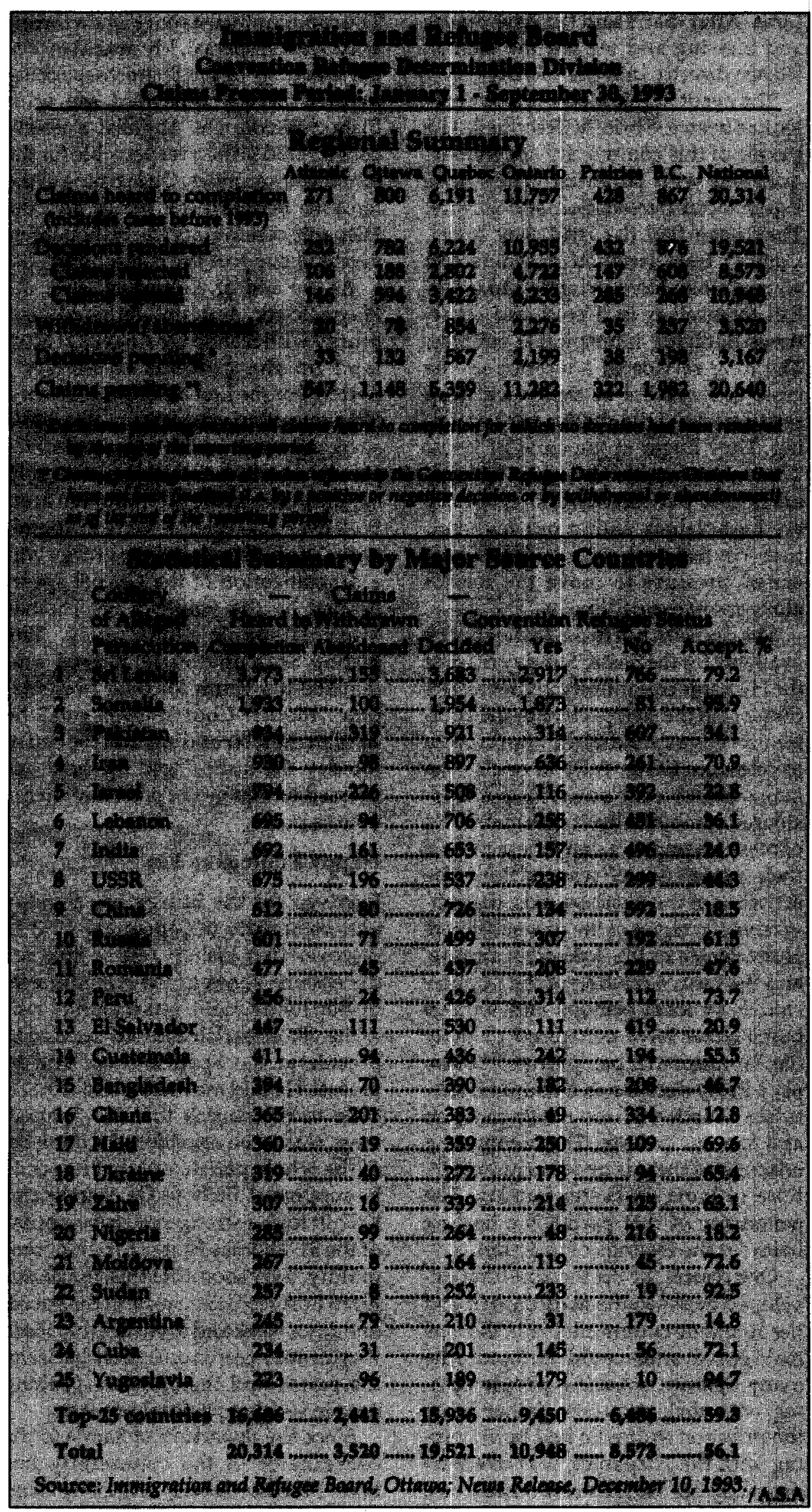

(C) Authors, 1994. This open-access work is licensed under a Creative Commons Attribution-NonCommercial 4.0 International

License, which permits use, reproduction and distribution in any medium for non-commercial purposes, provided the original author(s) are credited and the original publication in Refuge: Canada's Journal on Refugees is cited. 